\title{
Brasil: 1954 - Prenúncios de $1964^{\star}$
}

\section{Brazil: 1954, pressagies of 1964}

\author{
LUCILIA DE ALMEIDA NEVES DELGADO \\ Professora Titular de História e do Mestrado em Ciências Sociais - PUC/Minas. \\ Professora Participante do Programa de Pós-Graduação em História /UFMG. \\ Av: Dom José Gaspar, 500 Coração Eucaristíco - Belo Horizonte - MG - CEP 30535-610 \\ lucilianeves@terra.com.br
}

RESUMO O texto apresenta uma análise comparativa sobre duas conjunturas políticas conectadas da República do Brasil, situadas após a 2 ${ }^{-}$ Guerra Mundial: a primeira, em 1954, com a morte do Presidente Getúlio Vargas; a segunda, em 1964, com a deposição política do Presidente João Goulart.

Palavras-chave trabalhismo, getulismo, crise institucional.

ABSTRACT The text displays a comparative analysis about two connected political periods of Brasilian Republic after World War II, the first one in 1954, with the death of President Getulio Vargas, the second one in 1964, with the political withdrawal of President João Goulart.

Key words laborism, Vargas moviment, institutional crisis.

Artigo recebido em 30/04/2005; Aprovado em 17/05/2005. 


\section{O suicídio de Getúlio Vargas (1954):}

Vinte e quatro de agosto de 1954. Em seu romance, Ópera de Sabão, o escritor Marcos Rey apresenta ao leitor o cotidiano da vida do cidadão brasileiro na década de 1950, em que se ouviam bolero e sambas-canções, assistia-se a peças do Teatro Brasileiro de Comédia e escutavam-se radionovelas - apelidadas "óperas de sabão", por serem quase sempre patrocinadas por marcas de sabão e sabonete. ${ }^{1}$

Um dos personagens centrais da trama é o paulistano, descendente de italianos, Manfredo Manfredi, proprietário de uma pequena empresa de transportes, patriarca de uma família composta por mulher radialista e três filhos no auge da juventude. No dia da morte de Vargas, ao acordar, encharca-se de bebidas alcoólicas. Injuriado com a notícia do trágico suicídio do presidente, decide matar Carlos Lacerda, a quem considerava responsável pela imensa tragédia que se abatia sobre a nação brasileira. Com o revólver preso à cintura, Manfredi, que em 1945 havia participado da campanha queremista, anuncia solenemente à sua família que iria para o Rio de Janeiro. Queria vingar a perda extremada. Não consegue completar seu intento, pois, bêbado e desalentado, perambula pelas ruas de São Paulo, perdendo-se no emaranhado da cidade e nos braços de um ex-amor.

A reação passional e indignada de Manfredi, frente ao suicídio de Getúlio Vargas, corresponde à de milhares de brasileiros, especialmente de setores mais pobres da população, que entendiam ser o presidente um defensor de todos os trabalhadores do Brasil. Esses cidadãos tinham também um grande receio: de que a morte do presidente pudesse facilitar ações políticas destinadas a pôr fim ao modelo nacional-desenvolvimentista e trabalhista que vinha sendo implantado no Brasil pelas ações planejadoras e intervencionistas dos dois governos Vargas. O primeiro, iniciado em 1930 e finalizado em 1945, e o segundo, iniciado em 1951 e finalizado, com a tragédia do suicídio do presidente, em 1954.

\section{A deposição de João Goulart (1964)}

Primeiros meses do ano de 1964. No Brasil, as comemorações carnavalescas eram intensas e animadas por marchinhas e sambas como $A$ Cabeleira do Zezé, de João Roberto Kelly, e "Aquarela do Brasil", de Silas de Oliveira. Na música a Bossa Nova fazia sucesso, principalmente junto à juventude de classe média. O Teatro do Oprimido escancarava a miséria brasileira em encenações que se fizeram históricas, e o Cinema Novo também difundia forte crítica social e renovação estética. No dia

1 REY, Marcos. Ópera de Sabão. São Paulo: Companhia das Letras, 2003. 
treze de março, mesma data do famoso comício de João Goulart na Central do Brasil, Glauber Rocha estreava o filme Deus e o Diabo na Terra do Sol. A televisão, objeto de consumo de expressivos setores da classe média, introduzia em muitos lares brasileiros forte propaganda voltada para o consumo dos produtos industrializados que haviam chegado ao cotidiano da população brasileira poucos anos antes, quando da onda desenvolvimentista do governo Juscelino Kubsticheck.

Carlos Heitor Cony, em crônica intitulada "Da Salvação da Pátria", referente ao dia primeiro de abril daquele ano, narra sua experiência de um passeio acompanhado por Carlos Drummond de Andrade pelo posto seis do bairro de Copacabana, na cidade do Rio de Janeiro, onde militares que depuseram o presidente Goulart montavam barricada para enfrentar uma possível resistência do Primeiro Exército em apoio ao presidente deposto.

Naquele dia, de acordo com a crônica de Cony, as manifestações da população e de jovens militares em apoio aos "rebeldes" foram intensas. Rapazes bem nutridos erguiam o general que comandava a operação de resistência aos possíveis adeptos do presidente deposto. Papéis picados caíam das janelas dos apartamentos cobertas "por pios e alvacentos lençóis", em sinal de vitória. "Um cadillac conversível para perto do 'Six' e surge uma bandeira nacional". Cantam o hino nacional e declaram todos que a pátria está salva. ${ }^{2}$

O escritor também conta que sua filha the perguntou se as manifestações de rua eram festas de carnaval ou de comemoração à vitória em campeonato mundial. Respondeu que não e em seguida recolheu-se ao sossego, sentindo o gosto azedo da covardia.

O projeto nacional-desenvolvimentista e trabalhista, herança de Getúlio Vargas, foi abortado, mas a população que o apoiava não saiu às ruas para defendê-lo nessa oportunidade uma vez que, já no dia primeiro de abril, forte repressão se abateu sobre o país. Por sua vez, todos que se opunham ao modelo econômico e político nacionalista e mais popular defendido pelo governo Goulart comemoravam efusivamente a deposição do presidente, que para eles tinha um duplo sentido: fim do governo trabalhista de Jango e encerramento da "Era Vargas".

\section{4: fundamentos da crise institucional}

Em setembro de 1954, tomado por profunda emoção e ainda envolvido pelo calor dos acontecimentos que levaram ao suicídio do presidente Getúlio Vargas, Tancredo Neves, que fora seu Ministro da Justiça,

2 CONY, Carlos Heitor. Vozes do golpe: a Revolução dos caranguejos. São Paulo: Companhia das Letras, 2003. 
afirmou, em discurso pronunciado no plenário da Câmara dos Deputados, que forças nefastas se uniram contra o grande estadista. Para Tancredo, essas forças eram as seguintes:

Um partido conservador e antitrabalhista, por duas vezes derrotado em eleições democráticas em cujas fileiras - é preciso reconhecer - existem também verdadeiros patriotas iludidos na certeza de que servem aos seus verdadeiros ideais e não a interesses antinacionais - eis o elemento de fachada e a brigada de choque da grande conjura. Uma imprensa conservadora também ligada aos interesses dos grandes capitais nacionais e, por conseguinte, amalgamada no ódio a Getúlio Vargas e ao seu programa de governo, eis a máquina de agitação da opinião pública e de infiltração no seio das Forças Armadas, através do ludibrio das boas intenções de oficiais dignos e bemintencionados, mas, ao mesmo tempo, suscetíveis a uma determinada propaganda, por isso mesmo que saídos das classes mais abastadas. Por detrás de tudo isso e acima de tudo isso agia um grupo de notórios representantes do capital estrangeiro, de ricaços interessados em salvaguardar as suas gordas fontes de lucros em divisas. Por serem sabidamente ligados aos dinheiros estrangeiros, souberam manter-se no mais completo anonimato, arquitetando um plano cientifícamente traçado de destruição do governo Vargas e velando pela sua execução nos mínimos detalhes. Esses foram os verdadeiros autores da conspiração e os primeiros responsáveis pela morte de Vargas (...) Esses tristes inconfidentes da traição e da morte tinham nas mãos todos os cordões que movimentaram os títeres da implacável conspiração (...) No que toca às Forças Armadas, cumpre ressaltar que o ato de indisciplina e deslealdade ao seu Chefe Supremo a que foram levadas pela ação desagregadora de alguns líderes ambiciosos é, em grande parte, devido à ação de um grupo de oficiais da Escola Superior de Guerra". ${ }^{3}$

Já Samuel Wainer, amigo de Getúlio Vargas, fundador e editor do Jornal Última Hora, afirmou em seu livro, Minha Razão de Viver, que Vargas foi o maior líder burguês da história nacional, mas que somente os setores empresariais brasileiros não reconheceram esse fato. ${ }^{4}$

Processos, fatos, ações e discursos são sempre susceptíveis a diferentes análises e interpretações, tal qual demonstram os dois pronunciamentos de aliados de Vargas acima referidos, acerca das características e vinculações políticas e sociais do presidente.

Todavia, a crise institucional que culminou com seu suicídio apresenta um consenso interpretativo no que se refere à existência de uma forte e contundente oposição a seu governo. Oposição que muito contribuiu para a desestabilização governamental e para o desenlace final da própria crise que culminou com a morte do presidente e, por conseqüência, com seu afastamento do centro de poder na vida política brasileira.

3 NEVES, Tancredo de Almeida. O Governo Getúlio Vargas. In: DELGADO, Lucilia de Almeida Neves. Perfil parlamentar - Tancredo Neves. Brasília: Câmara dos Deputados - Centro de Documentação e Coordenação de Publicações, 2001, p.95. 
Mas como as entranhas da política são complexas e os processos representativos do exercício de poder e seus desdobramentos muitas vezes extrapolam a temporalidade delimitada de vida dos sujeitos da história, a morte de Getúlio Vargas acabou por não definir o final de sua influência no cenário político nacional, ao contrário do que desejavam seus adversários. Na verdade, o mito construído em torno da figura emblemática e carismática do estadista que, paradoxalmente, foi um caudiIho e um ditador, consolidou-se e se reproduziu ao longo de muitos anos no imaginário político da população brasileira e na herança concreta por ele deixada. Segundo Jorge Ferreira, "(...) o ditador do Estado Novo foi se alçando à categoria de maior mito da política brasileira, a ponto de fazer de sua morte nos anos 50 um evento ritual e reforçador das práticas democráticas no país". ${ }^{5}$

De fato, o período compreendido pelos anos de 1945 a 1964 foi caracterizado por um processo crescente, aprofundado e ampliado de democratização política e social do Brasil. Mas se Vargas, nessa etapa da trajetória política nacional brasileira, consolidou sua posição de mito político, não chegou a ser, todavia, como sugere Ferreira, um sujeito histórico que tenha tido papel relevante na ampliação da democracia política. Seu perfil autoritário, ao contrário, acabou também por contribuir para o aprofundamento da crise institucional de seu segundo governo. Por outro lado, forneceu argumentos para uma oposição que trazia, paradoxalmente, encoberta por seu discurso de defesa da democracia liberal, uma forte propensão autoritária. Os opositores de Vargas eram liberais autoritários que aos poucos perderam a inibição e ganharam eficácia em suas práticas políticas, que culminaram em ações articuladas, responsáveis pelo suicídio do presidente Vargas em 1954 e, dez anos depois, em 1964, pela deposição do presidente João Goulart.

Contudo, as críticas que identificam Vargas com práticas autoritárias não eram vazias de fundamento. Em 1950 o presidente foi eleito pela via democrática, mas trazia consigo uma cultura política centralizadora e autoritária, incompatível com a dinâmica da democracia política que, entre outros aspectos, supõe: funcionamento do Poder Legislativo, partidos políticos livres e atuantes, sociedade civil organizada e livre expressão de pensamento.

Em outras palavras, o modelo político do Estado Novo, ao qual havia se habituado e em que acreditava, não era compatível com ventos da democracia, que sopravam cada vez mais fortemente no cenário nacional. De 1950 a 1954, desenvolvendo forte crítica ao político veterano que

4 WAINER, Samuel. Minha razão de viver: memórias de um repórter. Rio de Janeiro: Record, 1988.

5 FERREIRA, Jorge. Trabalhadores do Brasil: o imaginário popular. Rio de Janeiro: Fundação Getúlio Vargas Editora, 1997, p.12. 
comandou a vida pública brasileira de 1930 a 1945 e que trazia entranhado em si uma cultura política autoritária, foi que as forças opositoras se manifestaram.

Mas se a imagem consolidada do político autoritário forneceu argumentos para o discurso e ação política das forças oposicionistas, outros fatores, de profunda relevância, também as impulsionaram em sua ação desestabilizadora de um governante que chegara, desta feita, ao Poder Executivo pelas vias legais e legítimas da democracia eleitoral. Em outras palavras, o discurso oposicionista referia-se de forma explícita a um político de marcado perfil autoritário; todavia, as mais profundas motivações que impulsionaram a oposição a Vargas sustentavam-se na enfática discordância que políticos da União Democrática Nacional (UDN), setores das Forças Armadas, segmentos do empresariado nacional e internacional e órgãos da grande imprensa tinham em relação ao projeto nacionalista e trabalhista do presidente.

Se a crítica ao autoritarismo atávico de Getúlio Vargas constituía a epiderme do discurso da oposição, sua principal divergência em relação ao governo do presidente petebista situava-se em terreno mais profundo. Referia-se a seu programa governamental, que incluía questões sociais e econômicas concernentes à essência de seu projeto para o país. Tal essência pode ser traduzida por quatro palavras: trabalhismo, nacionalismo, estatismo, desenvolvimentismo.

A trajetória do trabalhismo no Brasil, a qual se vincula um projeto peculiar de nacionalismo, estatismo e desenvolvimentismo distributivo, ganhou novas cores após 1945, quando foi fundado o Partido Trabalhista Brasileiro - PTB, ${ }^{6}$ identificado "pela estreita vinculação (...) com um projeto para o Brasil, que tinha como suporte principal uma concepção distributivista de bens e benefícios".

O PTB, partido com forte marca getulista desde a sua concepção e fundação, apresentou um programa que traduz, quase na integridade, o projeto de Getúlio Vargas para o Brasil. Dessa forma propunha, entre outras ações:

- defesa dos direitos trabalhistas;

- políticas sociais voltadas para garantia de emprego;

6 Sobre o trabalhismo no Brasil, incluindo o período anterior a 1945, destacam-se as seguintes obras: DELGADO, Lucilia de Almeida Neves. Trabalhismo, nacionalismo e desenvolvimentismo: um projeto para o Brasil (1945-1964). In: FERREIRA, Jorge (Org.). O Populismo e sua história: debate e crítica. Rio de Janeiro: Civilização Brasileira, 2001.; GOMES, Ângela Maria de Castro. Burguesia e trabalho: política e Legislação Social no Brasil. 1917/1937. Rio de Janeiro: Campus, 1979. Já sobre o Partido Trabalhista Brasileiro, alguns livros considerados importantes são: BENEVIDES, Maria Vitória. O PTB e trabalhismo: partido e sindicato em São Paulo (1945-1964). São Paulo: Editora Brasiliense, 1989.; D'ARAÚJO, Maria Celina. Sindicatos, Carisma e Pode: o Partido Trabalhista Brasileiro de 1945 a 1964. Rio de Janeiro: Fundação Getúlio Vargas, 1996.; DELGADO, Lucilia de Almeida Neves. PTB do Getulismo ao Reformismo - 1945-1964. São Paulo: Marco Zero, 1989.

7 DELGADO, Lucilia de Almeida Neves. Op.cit., 2001, p.175. 
- políticas públicas destinadas à qualificação do trabalhador;

- programa de previdência social ampla;

- políticas pública/sociais destinadas ao lazer, à saúde, à educação, à proteção à infância e à maternidade;

- política de planificação econômica dirigida pelo Estado;

- projetos de distribuição de renda e de "riquezas";

- incentivo ao cooperativismo econômico e à "solidariedade entre todos os cidadãos", visando à paz social. ${ }^{8}$

Com o tempo, a questão nacional, de absoluta relevância no projeto getulista, ganhou projeção maior no partido. Pode-se afirmar que, mesmo apresentando diferentes concepções e correntes internas, havia um eixo, uma espinha dorsal, que fez com que o trabalhismo petebista, filho primogênito do modelo getulista, se constituísse em um projeto para o Brasil. Trata-se, como já assinalado, do nacionalismo distributivo e desenvolvimentista, que pressupunha forte estatismo.

A crise que culminou com o suicídio de Vargas ganhou dimensão trágica na esteira das críticas que a oposição apresentava principalmente ao distributivismo social, ao nacionalismo econômico e ao estatismo, marcas concretas do modo de governar de Getúlio Vargas.

Todas as ações que udenistas, grande imprensa, setores das Forças Armadas e segmentos do capital internacional empreenderam, visando desestabilizar o governo Vargas, tinham, como pano de fundo, divergências estruturais relativas ao programa de governo do presidente. Dessa forma, fatos como: criação de uma Comissão Parlamentar de Inquérito relativa aos empréstimos do Banco do Brasil para o jornal Última Hora; divulgação do Manifesto dos Coronéis exigindo recomposição salarial; forte reação à proposta governamental de aumento de 100\% do salário mínimo em 1954; pressões objetivando a deposição do Ministro do Trabalho, João Goulart, também naquele ano; articulada e contundente campanha dos principais periódicos da grande imprensa contra o presidente Vargas, especialmente no calor da crise, também em 1954, todos tinham meta maior do que o afastamento de Vargas do poder.

$\mathrm{Na}$ verdade, o que estava em jogo eram dois projetos, ambos capitalistas, mas diferentes em suas metodologias e prioridades para o Brasil. Para a oposição, afastar Vargas significava, antes de tudo, abortar, de forma definitiva, um modelo social e econômico que, por se escudar em um forte discurso nacionalista/estatista, era incompatível com a internacionalização mais aprofundada da economia brasileira, por eles considerada mais moderna e eficaz para o país.

8 Itens retirados do Programa do PTB - Arquivo Getúlio Vargas - GV45000/1 - FGV - CPDOC -Rio de Janeiro. 
Para Dulci, o que os opositores de Vargas postulavam "era a adoção de um modelo de desenvolvimento associado ou interdependente...", com ênfase na iniciativa privada e na contenção à expansão do Estado. ${ }^{9}$

O suicídio de Getúlio Vargas, fato culminante da crise institucional que assolou o Brasil na primeira metade dos anos de 1950, afastou de forma definitiva o velho presidente do poder político. Mas sua atitude extrema de tirar a própria vida, ao sentir que o poder Ihe fugia, não correspondeu aos planos da oposição, que não pôde se contrapor à comoção nacional e à reação enfurecida dos populares, que tomaram as ruas das principais cidades do Brasil e que, como o personagem Manfredo Manfredi do romance de Marcos Rey, manifestaram toda sua indignação frente ao trágico fim de um presidente que sempre se preocupou com as questões social e nacional.

O forte vínculo de Vargas com os trabalhadores, responsável pela contundente comoção social e política quando de sua morte, é comprovado, de forma exemplar, pela "incrível história de Jacaré e seus companheiros de aventura", quatro pescadores que, no período do Estado Novo, viajaram, durante dois meses, do Ceará ao Rio de Janeiro, numa jangada, para falar com Getúlio Vargas e reivindicar que as leis trabalhistas fossem estendidas à sua categoria profissional. Ao chegar ao Distrito Federal foram recebidos por uma multidão e também em audiência pública pelo Presidente da República. Tiveram seus pleitos atendidos, pois

(...) Getúlio Vargas assinou um decreto incluindo a categoria no Instituto de Pensão e Aposentadoria dos Marítimos, instituindo um salário mínimo para a classe dos pescadores e sinalizando com a instalação, pelo Instituto do Marítimos, dentro de suas possibilidades, de postos de assistência e socorros médicos nas colônias de pesca. ${ }^{10}$

O mito de Vargas, construído a partir de sua estreita relação com os trabalhadores, como demonstra a história acima narrada, ganhou maior dimensão pelo sacrifício de sua auto-imolação. A partir dessa atitude repleta de significados e símbolos, iria assombrar seus opositores, que tiveram de adiar por alguns anos seus planos de chegada ao poder e de redefinição do modelo econômico brasileiro.

Entretanto, o suicídio do presidente, mesmo sendo um fato que consolidou sua imagem mítica no imaginário político e social da população brasileira, constituiu-se como prenúncio do que seria o futuro do Brasil. Sem dúvida, a deposição de João Goulart em 1964 significou a morte do

9 DULCl, Otávio Soares. A UDN e o antipopulismo no Brasil. Belo Horizonte: Editora da UFMG/PROED, 1986, p.42-43.

10 ABREU, Berenice. Odisséia numa jangada. Nossa História, Rio de Janeiro/ Biblioteca Nacional, ano I, n.8, p.18, 2004. 
projeto nacional-desenvolvimentista plantado por Getúlio Vargas. Morte prenunciada dez anos antes, no trágico agosto de 1954.

\section{4: a crônica de uma morte anunciada}

No dia treze de março de 1964, numa sexta-feira, às 18 horas, uma enorme multidão de cento e cinqüenta mil pessoas reuniu-se em um dos mais famosos eventos políticos da história republicana brasileira, o Comício da Central do Brasil, no qual o presidente João Goulart anunciou as primeiras de uma série de medidas referentes à adoção das "reformas de base" reivindicadas pelos movimentos sociais. "As bandeiras vermelhas que pediam a legalização do PC, as faixas que exigiam reforma agrária, etc foram vistas pela televisão, causando arrepios nos meios conservadores". ${ }^{11}$

Estimulado pelos aplausos de sindicalistas, camponeses, estudantes, políticos nacionalistas e, principalmente, populares não vinculados a organizações da sociedade civil, ${ }^{12}$ Jango, como era chamado por seus correligionários, assinou dois decretos. Um relativo à desapropriação das refinarias de petróleo que ainda não estavam nas mãos da Petrobrás e outro, denominado decreto da Supra (Superintendência da Reforma Agrária), que declarava sujeitas à desapropriação propriedades subutilizadas, especificando sua localização e dimensão. Também informou, em seu discurso, que estavam sendo preparadas as reformas urbana, universitária e tributária, além de propostas a serem encaminhadas ao Congresso Nacional, estendendo o direito de voto aos escalões inferiores das Forças Armadas.

Suas palavras eram acolhidas com fortes aplausos pelos presentes ao evento. Mas Goulart sabia que seus adversários, que acompanhavam o comício através de olheiros ou pela televisão, não as ouviam com a mesma satisfação de seus apoiadores. Tentou, portanto, em um ato derradeiro, neutralizar o impacto das medidas anunciadas, buscando, através de uma construção discursiva simbólica, sensibilizar as Forças Armadas para a causa reformista.

Se quiserem saber quais as cores que presidirão as reformas que serão realizadas, basta olhar a túnica de comandantes e comandados de nosso Exército,

11 FAUSTO, Boris. História do Brasil. São Paulo: Editora da Universidade de São Paulo/Fundação do Desenvolvimento da Educação, 1995, p.459.

12 Sobre os participantes no Comício da Central do Brasil é bastante elucidativa a informação contida no artigo de Ferreira, "O Governo Goulart e o Golpe Civil Militar de 1964", segundo a qual ali não estava uma maioria exclusiva de janguistas, que queriam que as reformas fossem implementadas a qualquer custo. Mas sim um público legalista, que defendia as reformas de base, mas que não admitia o fechamento do Congresso Nacional e esperava pelas eleições de 1965". In: FERREIRA, Jorge; DELGADO, Lucilia de Almeida Neves. O Brasil republicano: o tempo da experiência democrática — da democratização de 1945 ao golpe civil militar de 1964. Rio de Janeiro: Civilização Brasileira, 2003, v.3, p.384. 
da nossa Aeronáutica, da nossa Marinha, da nossa Polícia Militar. E ali, em cada túnica, encontrarão o verde-oliva que é o verde da bandeira brasileira. 0 azul da Aeronáutica e da nossa Marinha, que é o azul da bandeira brasileira. É com essas cores, verde, amarelo e azul, que faremos as reformas. ${ }^{13}$

A tentativa de Goulart, contudo, não alcançou os objetivos pretendidos, uma vez que os setores das Forças Armadas que não o apoiavam e que the faziam oposição não compartilhavam e nem compartilhariam jamais com tamanha iniciativa governamental de caráter reformista e também trabalhista / nacionalista.

$\mathrm{Na}$ verdade, a marca reformista do Governo João Goulart foi crescendo e se aprofundando à medida que seu governo perdia qualquer veleidade de cooptação ou mesmo apaziguamento da oposição e que, para se sustentar, necessitava de maior apoio dos movimentos sociais. Para esses movimentos, entretanto, a aliança com Jango deveria ser carimbada pela adoção sistemática pelo governo federal de políticas públicas efetivas voltadas para implementação das "reformas de base" e para o controle das remessas de lucro.

A João Goulart, que tinha um perfil reformista, mas que sempre afirmou não ser socialista, as alternativas políticas apresentadas acabaram por adquirir um caráter dicotômico. Ou recuava diante das pressões populares para neutralizar a oposição crescente a seu governo, ou abraçava a causa reformista dando-lhe as cores e a efetividade propugnadas pelas organizações da sociedade civil que lhe estavam mais próximas. Optou pela segunda alternativa, mesmo reconhecendo que o fantasma da desestabilização política, a partir dessa escolha, rondaria cotidianamente seu governo.

Nesse sentido, ao final de dezembro de 1963 assinou decreto que ampliava o monopólio da Petrobrás, estendendo-o à importação de petróleo e derivados. Em seguida, no mês de janeiro de 1964, regulamentou a Lei de Remessas de Lucros para o Exterior. Se tais medidas agradaram aos movimentos sindical, estudantil e camponês, causaram, por sua vez, profundo incômodo aos antigos adversários do trabalhismo getulista, que identificavam em Jango seu principal herdeiro, responsável por sua revitalização no início da década de 1960. Entendiam que urgia conter as iniciativas governamentais que pudessem apresentar qualquer vínculo, mesmo que simbólico, com o getulismo, ao qual denominavam de "populismo demagógico".

João Goulart havia sido Ministro do Trabalho de Getúlio Vargas no período de 1953 a 1954. Quando assumiu o cargo, os adversários do trabalhismo articularam uma campanha nacional contra sua nomeação.

13 GOULART, Jango. Discurso do Comício de Treze de Março. Citado por: VENTURA, Zuenir. Vozes do golpe: um voluntário da pátria. São Paulo: Companhia das Letras, 2004, p.22-23. 
Consideravam desde a década de 1950 que, além de apresentar perfil trabalhista "radical", era acessível aos comunistas e manipulável pelo movimento sindical. Já àquela época, para eles, a pior perspectiva possível seria a de que algum dia Jango se tornasse, como Getúlio Vargas, Presidente da República.

Entretanto, como resultado da crise política deflagrada pela renúncia de Jânio (anteriormente apoiado pelas forças conservadoras), aconteceu em 1961 o que mais temiam as forças antigetulistas: o estanceiro do Rio Grande do Sul, João Melchior Marques Goulart, chegou à presidência da República.

Era novamente um final do mês de agosto. Jânio Quadros, que havia sido eleito presidente com votação estrondosa e com o franco apoio do maior partido antivarguista da República Brasileira, a União Democrática Nacional (UDN), renunciou após somente sete meses de governo. A renúncia de Quadros levou ao desespero seus aliados políticos, que desde 1945 tentavam chegar à presidência da República, tendo sido derrotados em três eleições presidenciais consecutivas: a de 1945, quando foi eleito Eurico Gaspar Dutra do PSD; a de 1950, que elegeu o próprio Getúlio Vargas; e, por fim, a de 1955, que alçou ao poder o pessedista Juscelino Kubistcheck. Por ironia do destino, o vice-presidente de Jânio Quadros era João Goulart, que teria, não fosse a ação dos setores oposicionistas, direito imediato à posse como Presidente da República - assim previa a Constituição Brasileira.

Contudo, a reação imediata tanto dos ministros militares do presidente que havia renunciado, como da aguerrida União Democrática Nacional, foi a de tentar evitar que Goulart acendesse ao cargo máximo do Poder Executivo nacional. Para eles esse seria o pior dos pesadelos; significava, entre outros fatores, a reedição simbólica e concreta do getulismo, mesmo estando o velho presidente morto.

No contexto da renúncia de Jânio Quadros, os opositores de Goulart, além de sua aversão histórica ao trabalhismo getulista, respaldaram-se em um forte argumento de ocasião, pois o vice-presidente encontrava-se em viagem oficial à República Popular da China, fato que confirmava suas suspeitas de que Jango não se furtava a dialogar com os comunistas. ${ }^{14}$ No cenário da guerra fria, tal viagem foi vista pelos que a ele se opunham como um sinal inequívoco de que, sob sua direção, o Brasil poderia se tornar um parceiro dos países socialistas, ou então reforçar o movimento dos países não alinhados. Ambas as projeções o

14 No apogeu da guerra fria, Goulart era um obstinado defensor da ampliação das relações do Brasil com países não necessariamente vinculados ao bloco capitalista. Anteriormente, como vice-presidente de Juscelino Kubistcheck, visitou a União Soviética, fato que desagradou aos políticos anti-reformistas e aos setores mais conservadores das Forças Armadas. 
desviariam de uma aliança mais sólida com os países capitalistas e, em especial, com os Estados Unidos. Evitar sua posse era entendido, portanto, como tarefa necessária e inadiável.

Coincidência ou não, as posses presidenciais de Getúlio Vargas, em 1951, e de João Goulart, em 1961, foram antecedidas de forte crise política, pois a oposição, usando em cada uma das conjunturas de estratagemas diferentes, tentou impedi-las.

Com Getúlio Vargas o argumento foi de que o candidato do PTB não havia alcançado maioria absoluta de votos e que, portanto, não poderia ser empossado como presidente da República. A legislação eleitoral brasileira, contudo, não exigia a referida maioria absoluta de votos e Vargas acabou por tomar posse. Mas, desde o primeiro dia de seu mandato, teve que enfrentar uma oposição articulada e intransigente, que acabou por condicionar seu governo a uma crise permanente.

Já a posse de Goulart, precedida do veto dos ministros militares de Jânio Quadros, só se efetivou após dois movimentos: minuciosa negociação política no Congresso Nacional e pressão dos movimentos populares, que através da campanha pela legalidade, exigiam respeito à Constituição Brasileira. Entre as ações desenvolvidas pelos janguistas para garantir a posse de seu líder, destacaram-se os programas radiofônicos da "cadeia da legalidade", editada pelo também trabalhista Leonel Brizola, e uma greve nacional, convocada pelos sindicalistas e que se transformou no embrião do Comando Geral dos Trabalhadores do Brasil.

As pressões populares, que atingiram seu objetivo final - garantir a posse de Goulart, não tiveram, contudo, o gosto completo da vitória, pois o novo Presidente da República não assumiu o Poder Executivo com plenos poderes. Nas negociações que precederam sua posse, concebeu-se uma estratégia que visava limitar seus poderes presidenciais, atendendo em parte à pressão oposicionista. Foi instituído, então, um sistema de governo parlamentarista.

Jango, durante um período que se estendeu de setembro de 1961 a janeiro de 1963, viu-se compelido a dividir o poder com um primeiroministro. Todavia, a experiência parlamentarista foi complexa e contraditória, pois era no mínimo incompatível com a Constituição Brasileira, cujo teor era inteiramente presidencialista. João Goulart, por sua vez, se empenhou ao máximo para o retorno ao presidencialismo. Queria governar com plenos poderes presidenciais.

Mas a marca da crise inicial de seu mandato, tal como o segundo mandato de Vargas, contaminou todo seu período de governo, identificado por forte instabilidade. Além disso, feria sua legitimidade e dificultava o estabelecimento de efetivas condições de governabilidade.

Outra coincidência que aproxima as experiências governamentais dos dois presidentes foi o fato de que em seus mandatos aconte- 
ceram mudanças de rumos que alimentaram ainda mais o clamor oposicionista.

Com Vargas tal fato aconteceu a partir de 1953, quando, fatigado de tentar construir um governo de conciliação que contava inclusive com um membro da UDN no Ministério da Agricultura, o pernambucano João Cleófas, decidiu proceder a uma reforma ministerial. João Goulart, no conjunto dessa reforma, foi indicado para o Ministério do Trabalho, fato que muito desagradou a oposição. A partir dessa data, o governo de Vargas acentuou seu perfil trabalhista e nacionalista e teve que enfrentar as investidas de manifestações oposicionistas crescentes e contundentes, que culminaram com seu suicídio.

Dez anos depois, em 1963, após a realização de um plebiscito nacional, João Goulart passou a governar sob a égide do presidencialismo. Com seus poderes reconstituídos e também sentindo que não era possível articular qualquer tipo de consenso com a oposição, passou a adotar políticas acentuadamente nacionalistas e reformistas. Tal direção governamental, entretanto, se não chegou a satisfazer os movimentos sociais que reivindicavam um aprofundamento das referidas políticas, acabou por alimentar ainda mais os argumentos de seus adversários, que não Ihe deram trégua até o dia de sua deposição em 1964. Confirmava-se uma morte política já há muito anunciada.

\section{Getúlio Vargas e João Goulart: proximidades e diferenças}

Os nomes dos presidentes Getúlio Vargas e João Goulart são sempre relacionados à expressão "populismo", que pode ser entendida igualmente como um conceito, uma forma de governo ou uma prática política. "O ano de 1930 seria o início do populismo na política brasileira; 1945 marcaria rearranjos institucionais que teriam permitido a sua continuidade na experiência democrática; 1964, finalmente, significaria o seu colapso" ${ }^{15}$

Incorporada ao senso comum, a referida expressão também ganhou um sentido pejorativo, especialmente após a ascensão dos militares ao poder, que buscaram, de forma sistemática, identificá-la com certa forma demagógica de exercício do poder político, que segundo sua visão tinha em Vargas e em Jango seus principais representantes. ${ }^{16}$

Com a distensão política ao final dos anos de 1970 e com a ascensão do "novo sindicalismo", paradoxalmente, os novos líderes sindicais,

15 FERREIRA, Jorge. op cit., 2001, p.7.

16 Sobre a trajetória do conceito de "populismo" e suas inúmeras aplicações pode-se recorrer ao elucidativo ensaio de Ângela de Castro Gomes intitulado O populismo e as ciências sociais no Brasil; notas sobre a trajetória de um conceito in: FERREIRA, Jorge. Op.cit., 2001, p.17-57. 
que despontaram a partir das greves do $A B C$, ao final daquela década, também contribuíram para a desqualificação da experiência sindical do pré-1964, que era acentuadamente vinculada ao getulismo e ao janguismo, identificando-a, a princípio, como pelega e populista.

Tal posição dos novos líderes sindicais aos poucos foi sendo reformulada, mas não deixou de servir à causa da disseminação de uma imagem negativa da experiência trabalhista que vigorou no Brasil a partir de 1930, ganhou consistência no período autoritário de 1937 a 1945, mas se converteu em uma expressiva experiência democrática após 1945. ${ }^{17}$

Na verdade, a denominação "trabalhismo democrático" é a que melhor expressa as características do segundo governo Vargas (19501954) e do governo João Goulart (1961-1964). Governos esses que apresentaram vínculos e aproximações, mas que tiveram também marcas peculiares.

No terreno das similitudes, destacando-se em um primeiro momento os fatores externos que os desestabilizaram, sobressaíram os seguintes fatos:

- pressão permanente a que foram submetidos;

- contundente ação oposicionista, que dificultou a criação de condições de governabilidade;

- articulações voltadas em um primeiro momento para o impedimento da posse dos dois presidentes e, em seguida, para sua deposição;

- forma trágica que marcou o final dos dois mandatos presidenciais, pois foi principalmente em decorrência de pressões e articulações das oposições que Getúlio Vargas tirou a própria vida e João Goulart foi deposto por um golpe de Estado.

Quanto ao enfoque nas características comuns aos dois governos podem-se identificar inúmeras aproximações, dentre as quais destacamse:

- opção definida pela adoção de um projeto trabalhista de governo;

- forte enfoque distributivo,

- adoção de medidas de caráter nacionalista;

- compreensão de que o capitalismo poderia ser "humanizado", através da adoção de políticas sociais pelo Estado.

Mas se no plano das proposições substantivas havia uma nítida aproximação entre Vargas e Goulart, ambos vinculados à tradição do traba-

17 Sobre a posição do movimento sindical brasileiro que floresceu a partir das greves do ABC em relação ao movimento sindical do início dos anos de 1960 vide: SANTANA, Marco Aurélio. O "Novo" e o "Velho" sindicalismo: análise de um debate. Revista de Sociologia e Política, n.10 /11, 1998. 
Ihismo, cada um dos políticos teve uma maneira própria de governar. Isso a começar pelo fato de que Vargas foi mentor de um trabalhismo de corte autoritário, que reportava à época do Estado Novo, ao passo que Goulart afirmou-se em meio a um novo trabalhismo, reestruturado a partir da experiência política democrática que se iniciou em 1945 e que se inspirou em novas concepções como as do também gaúcho Alberto Pasqualini, que pode ser considerado o maior pensador do trabalhismo brasileiro. $^{18}$

Essas diferentes vinculações temporais influenciaram as práticas de governo dos dois presidentes, mas não mudaram o enfoque da oposição, que em muito influenciou a dinâmica de seus mandatos presidenciais. Seus opositores entendiam ser Vargas um eterno ditador que se respaldava em uma política demagógica e populista de cooptação dos trabalhadores. Entendiam também ser Goulart o principal herdeiro de Vargas que, além de trazer em si as mesmas características de seu inspirador, em muito contribuiu para a radicalização do trabalhismo, aproximando-o de um forte reformismo social e, pior ainda, do socialismo. Ambos foram considerados como forte ameaça ao aprofundamento e consolidação de um sistema econômico regido pela iniciativa privada, como afirma Dulci em obra já citada.

Mas se as similitudes entre os dois governantes trabalhistas eram substantivas, cada um também apresentou marca própria na condução de seus governos. A título de exemplo, destacam-se duas orientações.

O mandato de Vargas caracterizou-se por maior eficácia desenvolvimentista do que o de João Goulart, que teve que enfrentar forte crise econômica no decorrer de seu atropelado governo. Dessa forma, o período de 1951 a 1954 foi mais ousado na adoção de políticas industrializantes sustentadas por forte estatismo, traduzido principalmente pela criação da Petrobrás. Já Goulart, apesar de ter buscado investir e efetivar projetos como o da criação da Eletrobrás, apresentou uma marca mais social do que econômica em seu governo.

Outra orientação que distinguiu os dois governos relaciona-se à questão agrária. Vargas, dando continuidade à experiência de seu primeiro mandato presidencial, quando retornou à Presidência da República na década de 1950, também não implementou políticas públicas voltadas para uma melhor distribuição de terras no Brasil (questão da reforma agrária) e nem mesmo para a extensão da legislação trabalhista ao campo. Basta lembrar que o primeiro ministro da Agricultura do presidente

18 Fontes importantes para uma melhor compreensão da obra de Alberto Pasqualini são: PASQUALINI, Alberto. Bases e sugestões para uma política social. Rio de Janeiro: Livraria São José, 1958.; BODEA, Miguel. O Trabalhismo e o populismo: o caso do Rio Grande do Sul. Dissertação de Mestrado. São Paulo: USP, 1984; DELGADO, Lucilia de Almeida Neves, 2001.; DELGADO, Lucilia de Almeida Neves, 1989.; RUAS, Miriam Diehl. A doutrina trabalhista no Brasil (1945-1964). Porto Alegre: Sérgio Antônio Fabris Editor, 1986. 
Vargas, em seu segundo mandato, era vinculado, como já registrado, aos quadros da UDN.

Goulart, ao contrário, desenvolveu forte sensibilidade para a questão do campo. Sua postura fazia parte do elenco de prioridades de uma nova orientação do trabalhismo, que foi bastante atualizado após a morte de Vargas. Dessa forma, atendendo à forte pressão social por reforma agrária, que foi cotidiana no decorrer de seu governo e que apresentava marcas definidas desde o mandato presidencial de Juscelino Kubitscheck, não só adotou medidas efetivas para implementá-la como também estendeu a legislação trabalhista ao campo através do Estatuto do Trabalhador Rural (1963).

No decorrer do governo de Juscelino, inclusive, foi fundada a Frente Parlamentar Nacionalista (FPN), que passou a funcionar como caixa de ressonância das reivindicações nacionalistas e reformistas da sociedade civil junto ao Congresso Nacional. Também nesse período aconteceu uma forte expansão das Ligas Camponesas, que movimentaram o campo brasileiro com suas mobilizações em prol da reforma agrária. ${ }^{19}$

$\mathrm{Na}$ verdade, pode-se afirmar que Goulart, por fazer parte de uma nova geração de políticos trabalhistas que ganhou maior destaque na vida política brasileira, principalmente após 1954, acabou por adotar uma postura reformista bem mais acentuada do que a de Getúlio Vargas. Tal fato em muito contribuiu para acirrar os ânimos oposicionistas. Não foi por outra razão que durante seu mandato os políticos udenistas não Ihe deram trégua. Também para fazer frente ao crescimento do nacionalismo reformista, encampado pelo presidente Jango, foram criados dois institutos destinados a apoiar políticos com perfil anti-reformista e a divulgar forte propaganda contra o presidente petebista. Trata-se do Instituto Brasileiro de Ação Democrática (IBAD) e do Instituto de Políticas Econômicas e Sociais (IPES). ${ }^{20}$

Todavia, não se pode negar que tanto o trabalhismo tradicional quanto o trabalhismo renovado eram projetos sequer tolerados pelas forças liberais autoritárias que fizeram oposição a Getúlio Vargas e a João Goulart. Essas forças oposicionistas tiveram forte responsabilidade por um outro elemento comum às conjunturas dos dois governos: forte polarização política e ideológica.

19 Sobre a Frente Parlamentar Nacionalista, dois estudos da autora do presente ensaio podem ser consultados: DELGADO, Lucilia de Almeida Neves. "Partidos políticos e frentes parlamentares: projetos, desafios e conflitos na democracia". In: FERREIRA, Jorge. DELGADO, Lucilia de Almeida Neves, 2003, p.127-154.; e "Frente Parlamentar Nacionalista: utopia e cidadania". In: Revista Brasileira de História (27). São Paulo: ANPUH, 1994. Já sobre as Ligas Camponesas, dentre inúmeros estudos, destaca-se o seguinte: MONTENEGRO, Antônio Torres. "Ligas Camponesas e sindicatos rurais em tempo de revolução". In: FERREIRA, Jorge. DELGADO, Lucilia de Almeida Neves, 2003, p.241-272.

20 Sobre a atuação do IPES e do IBAD, dois livros clássicos contém relevantes informações e importantes análises: DREIFUSS, René Armand. 1964: a conquista do Estado. Petrópolis: Vozes, 1981 e STARLING, Heloísa. Os senhores das gerais: os novos inconfidentes e o golpe de estado de 1964. Petrópolis: Vozes, 1986. 
A polarização política que se exacerbou no decorrer do governo Vargas apresentava conteúdo muito personalizado e também muito vinculado às concepções divergentes sobre o melhor modelo para o desenvolvimento do capitalismo no Brasil. Na defesa dessas posições atuavam, principalmente, as seguintes organizações e setores:

\section{- oposição a Getúlio Vargas:}

- União Democrática Nacional;

- militares vinculados à Escola Superior de Guerra;

- setores do empresariado nacional;

- capital internacional;

- todos os principais jornais da grande imprensa;

- aliados de Getúlio Vargas:

- Partido Trabalhista Brasileiro;

- maioria expressiva do Partido Social Democrático;

- segmentos nacionalistas da Forças Armadas;

- movimento sindical;

· jornal Última Hora.

Já na conjuntura governamental na qual João Goulart foi Presidente da República a polarização ganhou maior complexidade, pois, além de incorporar concepções divergentes sobre o modelo de desenvolvimento mais adequado para o Brasil, foi marcada por forte conteúdo ideológico peculiar a um tempo no qual a bipolaridade e a guerra fria passavam por fase de forte acirramento. Amalgamada a esses fatores destacava-se a questão da reforma agrária, carro-chefe das propaladas "reformas de base". Sobressaía também a questão nacionalista, que, aos olhos da oposição, confundia-se com uma possível "simpatia" governamental pelo socialismo, pois os trabalhistas, que a princípio eram anticomunistas viscerais, realizaram um movimento de aproximação com o Partido Comunista Brasileiro a partir da segunda metade dos anos de 1950. A perspectiva do Brasil se aproximar do socialismo foi reforçada, na concepção das forças antiGoulart, por três acontecimentos: a Revolução Socialista Cubana de 1959 e as viagens de Jango à União Soviética e à China Popular.

No cenário político brasileiro do início dos anos de 1960 a polarização ideológica estava, portanto, representada pelas seguintes organizações, segmentos sociais e políticos do país:

- oposição a João Goulart:

- União Democrática Nacional, que tinha a seu lado outros partidos, como o Partido Republicano (PR) e o Partido Social Progressista (PSP); 
- Instituto Brasileiro de Ação Democrática e Instituto de Políticas Econômicas e Sociais

- setores do Partido Social Democrático;

- Escola Superior de Guerra e outros segmentos das Forças Armadas caracterizados por forte anticomunismo;

- setores conservadores da Igreja Católica;

- principais jornais da grande imprensa;

- grandes latifundiários e demais proprietários de terras;

- segmentos da classe média, inclusive mulheres que formaram, por

exemplo, os quadros da Campanha da Mulher pela Democracia (CA-

MDE) e a Liga da Mulher Democrática (LIMDE);

- a maior parte do empresariado nacional;

- investidores internacionais;

- governadores de diferentes estados da Federação, destacando-se Carlos Lacerda do estado da Guanabara, Adhemar de Barros do estado de São Paulo e Magalhães Pinto, de Minas Gerais. ${ }^{21}$

- aliados de João Goulart:

- Partido Trabalhista Brasileiro, que tinha a seu lado o Partido Socialista Brasileiro e o Partido Comunista;

- Frente Parlamentar Nacionalista;

- movimento sindical, em especial os sindicatos vinculados ao Comando Geral dos Trabalhadores do Brasil (CGT);

- movimentos de camponeses, através das Ligas Camponesas e sindicatos rurais;

- movimento estudantil, através da União Nacional dos Estudantes (UNE) e das uniões estaduais dos estudantes (UEEs);

- alguns segmentos nacionalistas e constitucionalistas das Forças Armadas;

- baixo escalão das Forças Armadas;

- setores progressistas da Igreja Católica;

- alguns governadores como: Miguel Arraes de Pernambuco, Leonel

Brizola do Rio Grande do Sul e Seixas Dória de Sergipe.

O cenário do conflito era complexo, estendia-se das organizações políticas à sociedade civil, apresentava forte interferência internacional e traduzia um conflito ideológico profundo que incluía entre seus ingredientes a antiga querela entre defensores do trabalhismo getulista e tradicionais adversários de Getúlio Vargas.

21 Sobre a heterogeneidade dos grupos que se uniram para derrubar o governo João Goulart, instigante análise pode ser encontrada in: MOTTA, Rodrigo Pato Sá. "João Goulart e crise de 1964 no traço da caricatura". In: REIS, Daniel; RIDENTI, Marcelo; MOTTA, Rodrigo Pato Sá. O golpe e a ditadura militar 40 anos depois (19642004). Bauru/SP: EDUSC, 2004, p.179-201. 
A história é um processo marcado por rupturas e continuidades. $O$ ano de 1964 nasceu marcado pela continuidade de profundas desavenças políticas que alimentavam a história brasileira desde 1930. Divergências que se tornaram mais complexas a partir do início da década de 1964, mas que reeditavam velhas tramas e conflitos. Dez anos após o suicídio de Getúlio Vargas, o filme sobre a história brasileira parecia, de alguma forma, reeditado, desta feita incorporando novos personagens e provocando uma ruptura que havia sido ensaiada em 1954.

O ano de 1954, portanto, pode ser entendido como prenúncio de 1964. Com a deposição e exílio de João Goulart chegava ao fim a Era Vargas e o tempo do trabalhismo distributivo. Getúlio Vargas continuou presente na história brasileira como um mito quase que inatingível. Mas, a respeito de João Goulart passou-se uma esponja de esquecimento e de desqualificação. A memória oficial, com todo o poder que the é inerente, de forma avassaladora sobrepujou a memória dos vencidos.

\section{REFERÊNCIAS BIBLIOGRÁFICAS}

ABREU, Berenice. Odisséia numa jangada. Nossa História, Rio de Janeiro/ Biblioteca Nacional, ano I, n.8, p. 18, 2004.

BENEVIDES, Maria Vitória. O PTB e trabalhismo: partido e sindicato em São Paulo (19451964). São Paulo: Editora Brasiliense, 1989.

BODEA, Miguel. O Trabalhismo e o populismo: o caso do Rio Grande do Sul. Dissertação de Mestrado. São Paulo: USP, 1984.

CONY, Carlos Heitor. Vozes do golpe: a Revolução dos caranguejos. São Paulo: Companhia das Letras, 2003.

D'ARAÚJO, Maria Celina. Sindicatos, Carisma e Poder: o Partido Trabalhista Brasileiro de 1945 a 1964. Rio de Janeiro: Fundação Getúlio Vargas, 1996.

DELGADO, Lucilia de Almeida Neves. "Trabalhismo, nacionalismo e desenvolvimentismo: um projeto para o Brasil (1945-1964)". In: FERREIRA, Jorge (Org.). O Populismo e sua história: debate e crítica. Rio de Janeiro: Civilização Brasileira, 2001.

DELGADO, Lucilia de Almeida Neves. PTB do Getulismo ao Reformismo - 1945-1964. São Paulo: Marco Zero, 1989.

DELGADO, Lucilia de Almeida Neves. "Partidos políticos e frentes parlamentares: projetos, desafios e conflitos na democracia". In: FERREIRA, Jorge; DELGADO, Lucilia de Almeida Neves, 2003, p.127-154.

DELGADO, Lucilia de Almeida Neves. "Frente Parlamentar Nacionalista: utopia e cidadania". Revista Brasileira de História, São Paulo/ ANPUH, v.27, 1994.

DREIFFUS, René Armand. 1964: a conquista do Estado. Petrópolis: Vozes, 1981.

DULCI, Otávio Soares. A UDN e o antipopulismo no Brasil. Belo Horizonte: Editora da UFMG / PROED, 1986.

FAUSTO, Boris. História do Brasil. São Paulo: Editora da Universidade de São Paulo / Fundação do Desenvolvimento da Educação, 1995.

FERREIRA, Jorge; DELGADO, Lucilia de Almeida Neves. O Brasil republicano: o tempo da experiência democrática — da democratização de 1945 ao golpe civil militar de 1964. Rio de Janeiro: Civilização Brasileira, 2003.

FERREIRA, Jorge. Trabalhadores do Brasil: o imaginário popular. Rio de Janeiro: Fundação Getúlio Vargas Editora, 1997, p.12. 
GOMES, Ângela Maria de Castro. Burguesia e trabalho: política e Legislação Social no Brasil. 1917/1937. Rio de Janeiro: Campus, 1979.

GOMES, Ângela de Castro. O Populismo e as ciências sociais no Brasil: notas sobre a trajetória de um conceito. In: FERREIRA, Jorge. O Populismo e sua história - debate e crítica. Rio de Janeiro: Civilização Brasileira, 2001.

GOULART, Jango. Discurso do Comício de Treze de Março. In: VENTURA, Zuenir. Vozes do golpe: um voluntário da pátria. São Paulo: Companhia das Letras, 2004, p.22-23.

MONTENEGRO, Antônio Torres. "Ligas Camponesas e sindicatos rurais em tempo de revolução". In: FERREIRA, Jorge; DELGADO, Lucilia de Almeida Neves. 2003, p.241272.

MOTTA, Rodrigo Pato Sá. João Goulart e crise de 1964 no traço da caricatura. In: REIS, Daniel; RIDENTI, Marcelo; MOTTA, Rodrigo Pato Sá. O golpe e a ditadura militar - 40 anos depois (1964-2004). Bauru/SP: EDUSC, 2004.

NEVES, Tancredo de Almeida. O Governo Getúlio Vargas. In: DELGADO, Lucilia de Almeida Neves. Perfil parlamentar - Tancredo Neves. Brasília: Câmara dos Deputados - Centro de Documentação e Coordenação de Publicações, 2001, p.95.

PASQUALINI, Alberto. Bases e sugestões para uma política social. Rio de Janeiro: Livraria São José, 1958.

PROGRAMA DO PTB - Arquivo Getúlio Vargas - GV45000/1 - FGV - CPDOC - Rio de Janeiro.

REY, Marcos. Ópera de Sabão. São Paulo: Companhia das Letras, 2003.

RUAS, Miriam Diehl. A doutrina trabalhista no Brasil (1945-1964). Porto Alegre: Sérgio Antônio Fabris Editor, 1986.

STARLING, Helísa. Os senhores das gerais os novos inconfidentes e o golpe de 1964. Petrópolis: Vozes, 1986.

WAINER, Samuel. Minha razão de viver: Memórias de um repórter. Rio de Janeiro: Record, 1988. 